\title{
ANTIBIOTIC RESISTANCE IN Escherichia coli ISOLATED FROM FECES OF BALI CATTLE WITH REPRODUCTIVE DISORDERS
}

\author{
Kholik*1,5, Muhammad Munawaroh $^{2}$, Muhammad Rama Imam Saputra ${ }^{3}$, \\ Rahmawati $^{4}$, Pudji Srianto ${ }^{5}$
}

Received : October 29, 2021

Accepted : September 11, 2021

DOI: 10.15575/biodjati.v6i2.13925

${ }^{1,2,3}$ Faculty of Veterinary Medicine, Universitas Pendidikan Mandalika, Jl. Pemuda No.59A, Mataram City 83125

${ }^{4}$ Balai Laboratorium Kesehatan Pengujian dan Kalibrasi Propinsi Nusa Tenggara Barat, Jl. Catur Warga No.4, Mataram City 83121

${ }^{5}$ Faculty of Veterinary Medicine, Universitas Airlangga, Mulyorejo,

Surabaya City, East Java 60115 e-mail:

*1kholiqvet@gmail.com

²m.munawaroh@gmail.com

${ }^{3}$ ramassaputra@ymail.com

4rahmawwatithamrin15@ymail.com

5pudjisrianto@yahoo.com

*Corresponding author

Abstract. Antimicrobial resistance (AMR) has become a global issue in animal, human and environmental health. The AMR profile of Escherichia coli reflects the use of antibiotics in production animals. The purpose of this study was to determine the antibiotic resistance of Escherichia coli bacteria isolated from the feces of female Bali cattle with reproductive disorders. Feces samples were taken purposively using a swab on 4 rectums from 7 Bali cattle with reproductive disorders in June 2021 in Lando Village, East Lombok Regency. Escherichia coli samples were isolated on Eosin Methylene Blue Agar media and identified by biochemical tests. An antibiotic resistance test against Escherichia coli was carried out by the disk diffusion method. The antibiotics used in the test were Penicillin G 10 $U$, Oxytetracycline $30 \mathrm{~g}$, Gentamicin $10 \mathrm{~g}$, and Tetracycline $30 \mathrm{~g}$, and Cefotaxime $30 \mathrm{~g}$. The results of planting on Eosin Methylene Blue Agar media obtained 4 Escherichia coli which were successfully isolated from 4 samples of Bali cattle feces. Data on the level of Escherichia coli susceptibility level to various antibiotics were analyzed using the chi-square test. The results of the susceptibility test to antibiotics showed that 4 samples of Escherichia coli (100\%) were resistant to Penicillin G, (25\%) were resistant to Oxytetracycline, (25\%) were resistant to Cefotaxime, and (100\%) samples of Escherichia coli were sensitive to Gentamicin and Tetracycline. The chi-square test on the level of Escherichia coli susceptibility to various antibiotics was significant with $p<0.05$ ( $p$-value $=0.012$ ). The results of this study have shown that Escherichia coli from Bali cattle feces experience multidrug resistance which later on might have an impact on human health and the environment.

Keywords: antibiotic, Bali cattle, Escherichia coli, reproductio,

\section{Citation}

Kholik, Munawaroh, M., Saputra, M. R. I., Rahmawati, Srianto, P. (2021). Antibiotic Resistance in Escherichia coli Isolated from Feces of Bali Cattle With Reproductive Disorders. Jurnal Biodjati, 6(2), 303-311.

\section{INTRODUCTION}

Reproductive disorders in female cows are still the main obstacle in achieving the need for protein from animal origin. Bacterial infection is one of the causes of reproductive disorders in cattle. This bacterial infection in female cows is mainly caused by repeated mating, metritis, and is related to the use of antibiotics. Unmanagable use of antibiotics 


\section{JURNAL BIDDJATI}

http://journal.uinsgd.ac.id/index.php/biodjati

for reproductive disorders in female cows on cattle causes bacteria to mutate leading to antibacterial resistance. Antimicrobial resistance (AMR) has become a global issue in both animal and human health. AMR has killed about 700,000 people, and by 2050 this number is expected to increase to about 10 million deaths each year (O'Neill, 2016). One of the bacteria that cause antibiotic resistance that widely discussed is Escherichia coli as an indicator bacterium of animal origin.

Escherichia coli is used as an indicator because the AMR profile of E. coli almost reflects the use of antimicrobials in animals for food production (EFSA, 2011). Previous research data on the island of Lombok documented that $E$. coli had been isolated from Bali cattle with reproductive disorders in Central Lombok (Aminuddi et al., 2020). Gunawan et al. (2018) have reported that among $94.4 \%$ of $E$. coli were isolated from 20 samples of Bali cattle feces in smallholder farms in Central Lombok, $61 \%$ of $E$. coli samples were resistant to Erythromycin and Tetracycline, and $16.7 \%$ of E. coli samples were resistant to Ciprofloxacin. E. coli that cause multidrug resistance has been detected in $8.6 \%$ of 220 samples of cow feces at slaughterhouses in Bogor (Sudarwanto et al., 2016). E. coli which produces TEM-type Extended-spectrum $\beta$-lactamase (ESBL) and CTX-M gene have also been found in cattle feces and the environment in Peninsular Malaysia (Kamaruzzaman et al., 2020).

The island of Lombok, West Nusa Tenggara Province, is rich in traditional livestock groups that keep Bali cattle as beef cattle for meat production, which is still constrained by cases of reproductive disorders. Dibia et al. (2015) stated that the number of cases of reproductive disorders found was 2,127 cases, namely endometritis as many as 533 cases (25.1\%), repeat breeders
530 cases $(24.9 \%)$, ovarian hypofunction 517 cases $(24.3 \%)$, silent heat 368 cases $(17.3 \%)$, persistent corpus luteum 89 cases $(4.2 \%)$, cystic follicles 72 cases $(3.3 \%)$, and pyometra 18 cases $(0.8 \%)$. Cases of high reproductive disorders certainly cannot be separated from the use of antibiotics in their treatment. Administration of antibiotics such as penicillin and oxytetracycline for 3 to 5 days has been done to reduce bacterial infections in cases of retained placenta (Yusuf, 2016). Intra-uterine administration of Gentamicin, Flumequine, and PGF $2 \alpha$ in cases of endometritis has also been carried out (Melia et al., 2014). The future impact that poses a threat is the excretion of $E$. coli producing Extendedspectrum $\beta$-lactamase (ESBL) through feces due to uncontrolled use of antibiotics that can contaminate the environment, food ingredients that can interfere with human health and the environment. FAO (2016) states that the use of antimicrobial drugs in health care, agriculture, or industry creates selection pressures that can support the survival of resistant bacterial strains thereby increasing the presence of antimicrobialresistant bacteria in their communities.

Based on the facts of cases of high reproductive disorders in Bali cattle in West Nusa Tenggara, research is needed to determine antibiotic resistance in $E$. coli bacteria in traditional livestock groups that keep Bali cattle as beef cattle as a reflection of the use of antimicrobials in animals and as initial data about the presence of $E$. coli producing antibiotic-resistant genes that can threaten human health and the environment.

\section{MATERIALS AND METHODS}

This research was an observational descriptive with a cross-sectional study and was conducted in June 2021 at the Pade Angen 


\section{JURNAL BIDDJATI}

http://journal.uinsgd.ac.id/index.php/biodjati

Livestock Farmer Group in Lando Village, East Lombok Regency. Feces samples were taken purposively using a swab on 4 rectums of Bali cattle from 7 female Bali cattle with reproductive disorders based on the inseminator report. Samples were put in Brain Heart Infusion (BHI) media and incubated for 24 hours at $37^{\circ} \mathrm{C}$ at the Health Testing and Calibration Laboratory of West Nusa Tenggara Province. The samples were then cultured on Eosin Methylene Blue Agar (EMBA) media and incubated for 24 hours at $37^{\circ} \mathrm{C}$ to grow $E$. coli. The growing $E$. coli were then identified by gram staining and biochemical tests before being tested for resistance. Assessment of the results of biochemical tests including Triple sugar iron (TSI), Sulfide Indole Motility (SIM), and fermentation of lactose, glucose, fructose \& mannitol refers to Basic laboratory procedures in clinical bacteriology (Vandepitte et al., 2003)

Escherichia coli resistance to antibiotics was tested by disk diffusion on Mueller Hinton Agar using the Kirby Bauer method. E. coli colonies took from EMBA media and then put into a test tube containing $0.9 \% \mathrm{NaCl}$ and homogenized to reach the Mc Farland standard of 0.5 . The E. coli suspension which had reached the standard Mc Farland 0.5 was then swabbed on Mueller Hinton Agar media evenly and allowed to stand for 5 minutes and then 5 types of antibiotics were planted, including Penicillin G $10 \mathrm{U}$, Oxytetracycline $30 \mathrm{~g}$, Gentamicin $10 \mathrm{~g}$, and Tetracycline $30 \mathrm{~g}$ and Cefotaxime $30 \mathrm{~g}$ and incubated for 24 hours at $37^{\circ} \mathrm{C}$. Penicillin and Cefotaxime antibiotics were used in this study because they are beta-lactam antibiotics, specifically, Cefotaxime is a third-generation cephalosporin antibiotic used as an indication of the presence of ESBL-producing bacteria. Oxytetracycline which is a tetracycline group was used because this antibiotic has been used in the treatment of large animals, either short- acting or long-acting. Tetracycline was used as a comparison to Oxytetracycline because commonly used of tetracycline by humans. While Gentamicin was used because it has been used for reproductive disorders such as metritis in combination with Prostaglandin F2 alpha (PGF2 $\alpha$ ) (Melia et al., 2014). Susceptibility to antibiotics was carried out by measuring the diameter of the inhibition zone formed by using a caliper. Sensitive (S), intermediate (I), and resistant (R) assessments were determined by the size of the inhibition zone formed based on the Clinical and Laboratory Standards Institute standards (CLSI, 2012). E. coli isolate of American Type Culture Collection (ATCC) type 25922 was used as a control in resistance testing in this study.

The data from the identification of E.coli based on gram staining and biochemical tests, as well as the test of E. coli resistance to antibiotics, will be presented in the form of figures and tables that are compared with the value of antibiotic susceptibility to bacteria based on the Clinical and Laboratory Standards Institute standards (CLSI, 2012). Data on the level of susceptibility of E. coli to various antibiotics will be analyzed using the chi-square test.

\section{RESULTS AND DISCUSSION}

The results of planting 4 fecal samples of female Bali cattle with reproductive disorders on Eosin Methylene Blue Agar (EMBA) obtained 4 samples of $E$. coli which were successfully isolated. Morphological images of $E$. coli in EMBA can be seen in Figure (1). E. coli colonies grown in Eosin Methylene Blue Agar (EMBA) media (Figure 1) showed that the growing E. coli was metallic green, mucoid in shape with a dark center. These results are are similar to the results of the isolation of $E$. coli in Bali cattle feces on local 


\section{JURNAL BIDDJATI}

http://journal.uinsgd.ac.id/index.php/biodjati

farms in Central Lombok Regency (Gunawan et al., 2018).

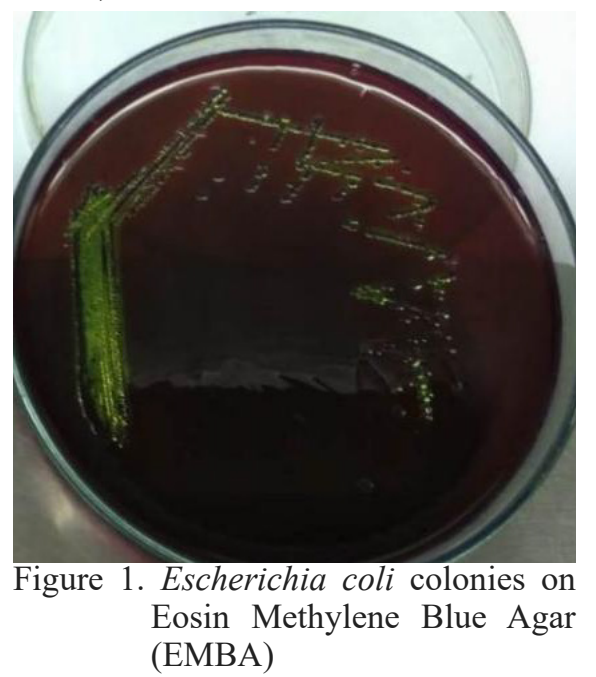

The same results were also shown in the study by Saputra et al. (2018) who succeeded in isolating $E$. coli from bat droppings on the island of Sumbawa, Nusa Tenggara Barat Province, Indonesia. This indicates that $E$. coli colonies derived from feces from both domestic and wild animals showed almost the same morphology on EMBA media with a metallic green color with a dark center.

The results of the gram staining of $E$. coli isolates from the feces of female Bali cattle with reproductive disorders are presented in (Figure 2).

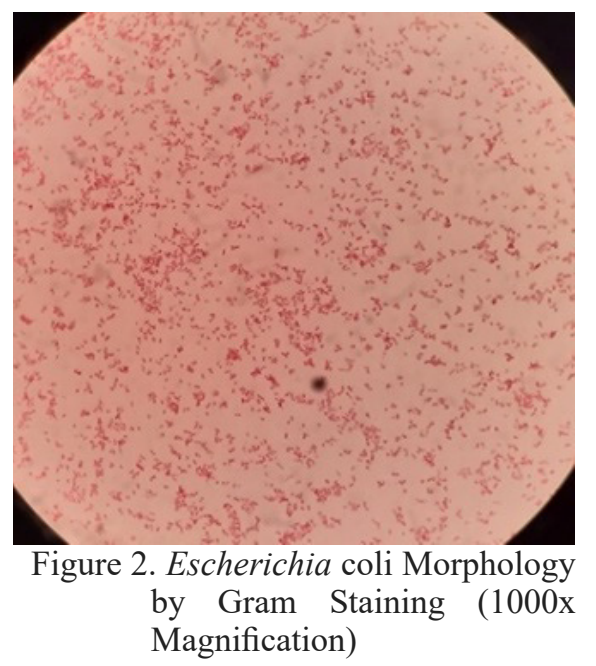

The results of the gram staining showed that $E$. coli has the shape of a short rod and is gram-negative (Figure 2). Cornelisse et al. (2013) stated that E. coli is a gramnegative bacterium, facultative anaerobic with morphology in the form of a short rod with a length of about $2 \mu \mathrm{m}$, a diameter of 0.7 $\mu \mathrm{m}$, a width of $0.4-0.7 \mu \mathrm{m}$. The results of the biochemical test of $E$. coli isolated from Bali cattle feces are presented in Table (1). The results of the biochemical test state that $E$. coli isolated from Bali cattle feces were catalasenegative and oxidase-negative, fermented glucose, lactose, sucrose, maltose, mannitol, and positive for Indole test. The E. coli also did not use citrate in Simon Citrate Agar. E. coli was also motile in Sulfide Indole Motility (SIM) media and produced acid and $\mathrm{H}_{2} \mathrm{~S}$ in Triple Sugar Iron Agar (TSIA).

This biochemical test results are almost the same as previous studies which stated that $E$. coli isolates from Bali cattle feces by fermenting Glucose, sucrose, Indole was positive and did not produce urea (Gunawan et al., 2018). The results are still in line with the characteristics of $E$. coli which produces gas during carbohydrate fermentation and indole shows positive results. Cornelissen et al. (2013) stated that E. coli produces acid and gas during carbohydrate fermentation. E. coli in methyl red and indole tests showed positive results and negative reactions for the VogesProskauer test and citrate, the results of these tests that distinguish them from other digestive tract bacteria (Cornelissen et al., 2013). This statement is corroborated by the research of Aminuddi et al. (2020) who documented that E.coli isolated from the reproductive tract of Bali cattle ferment carbohydrates and produce gas. E. coli with the same biochemical results have also been isolated from anal swabs in bats, where E. coli ferments glucose and lactose (Kholik et al., 2019). 


\section{JURNAL BIDDJATI}

http://journal.uinsgd.ac.id/index.php/biodjati

The results of the susceptibility test of 4 samples of Escherichia coli bacteria from Bali cattle feces to antibiotics that are often used in livestock, namely Penicillin G $10 \mathrm{U}$, Oxytetracycline $30 \mathrm{~g}$, Gentamicin $10 \mathrm{~g}$, and Tetracycline $30 \mathrm{~g}$, and Cefotaxime $30 \mathrm{~g}$ disc diffusion method on MHA (Mueller Hinton Agar) media are presented in Figure 3.

Figure 3 shows that all samples of E. coli from the feces of female Bali cattle with reproductive disorders did not form an inhibitory zone against Penicillin G, while for
Oxytetracycline, Gentamicin, and Tetracycline and Cefotaxime varied. Table 2 shows the results of the resistance test of 4 samples of $E$. coli that were isolated from the feces of Bali cattle with reproductive disorders. It was found that 4 samples of Escherichia coli $(100 \%)$ were resistant to Penicillin G, $(25 \%)$ were resistant to Oxytetracycline, $(25 \%)$ resistance to Cefotaxime, and 4 (100\%) Escherichia coli samples were sensitive to Gentamicin and Tetracycline.

Table 1. The Result of the Biochemical test of Escherichia coli from Bali cattle feces

\begin{tabular}{l|l}
\hline Biochemical Test & \multicolumn{1}{c}{ Results } \\
\hline Catalase & - \\
Oxidase & + \\
Glucose Fermentation & + \\
Lactose Fermentation & + \\
Sucrose Fermentation & + \\
Maltose Fermentation & + \\
Mannitol Fermentation & + \\
Indole Test & - \\
Simon Citrate Agar & Motil \\
Sulfide Indole Motility (SIM) & Acid/Acid $+\mathrm{H}_{2} \mathrm{~S}$ \\
\hline Triple Sugar Iron Agar (TSIA)
\end{tabular}
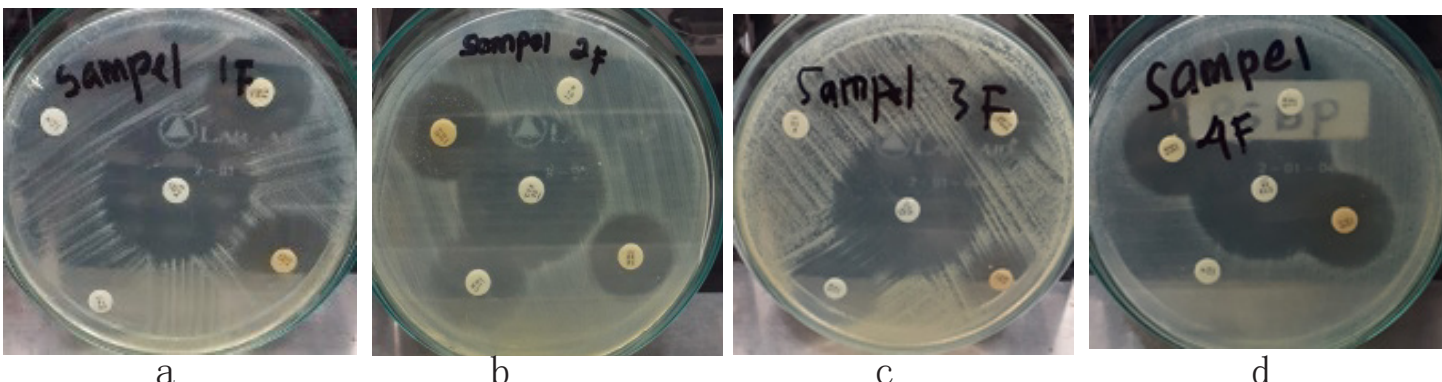

Figure 3. The results of the Susceptibility Test of Escherichia coli to MHA (Mueller Hinton Agar). Description: $a=$ sample $1, b=$ sample $2, c=$ sample $3, d=$ sample 4 ; (black arrow) = zone of inhibition 


\section{JURNAL BIDDJATI}

http://journal.uinsgd.ac.id/index.php/biodjati

Table 2. Diameter of inhibition zone of Escherichia coli isolates against various antibiotics

\begin{tabular}{|c|c|c|c|c|c|}
\hline \multirow[b]{2}{*}{ Sample } & \multicolumn{5}{|c|}{ Diameter of Inhibition Zone of Escherichia coli Isolates Against Various Antibiotics } \\
\hline & $\begin{array}{c}\text { Penicillin } G \\
(S>17, I=14- \\
16, R \leq 13)\end{array}$ & $\begin{array}{l}\text { Oxytetracycline } \\
(\mathrm{S}>15, \mathrm{I}=12-14 \\
\mathrm{R} \leq 11)\end{array}$ & $\begin{array}{c}\text { Gentamicin } \\
(\mathrm{S}>15, \mathrm{I}=13-14, \\
\mathrm{R} \leq 12)\end{array}$ & $\begin{array}{c}\text { Tetracycline } \\
(\mathrm{S}>15, \mathrm{I}=12-14, \\
\mathrm{R} \leq 11)\end{array}$ & $\begin{array}{c}\text { Cefotaxime } \\
(\mathrm{S}>26, \mathrm{I}=23-25, \\
\mathrm{R} \leq 22)\end{array}$ \\
\hline 1 & $0 \mathrm{R}$ & $25 \mathrm{~S}$ & $25 \mathrm{~S}$ & $25 \mathrm{~S}$ & $30 \mathrm{~S}$ \\
\hline $\begin{array}{l}2 \\
3\end{array}$ & $\begin{array}{l}0 \mathrm{R} \\
0 \mathrm{R}\end{array}$ & $\begin{array}{l}0 \mathrm{R} \\
20 \mathrm{~S}\end{array}$ & $\begin{array}{l}25 \mathrm{~S} \\
28 \mathrm{~S}\end{array}$ & $\begin{array}{l}20 \mathrm{~S} \\
18 \mathrm{~S}\end{array}$ & $\begin{array}{l}30 \mathrm{~S} \\
20 \mathrm{R}\end{array}$ \\
\hline 4 & $0 \mathrm{R}$ & $25 \mathrm{~S}$ & $18 \mathrm{~S}$ & $24 \mathrm{~S}$ & $36 \mathrm{~S}$ \\
\hline
\end{tabular}

Table 3. Category on Escherichia coli susceptibility level to various Antibiotics

\begin{tabular}{lllll}
\hline & \multicolumn{3}{c}{$\begin{array}{c}\text { Escherichia coli } \\
\text { Susceptibility }\end{array}$} & \\
\cline { 1 - 4 } Type of Antibiotics & Susceptible & Resistant & Total & P-value \\
\hline Penicillin G & 0 & 4 & 4 & 0.012 \\
\hline Oxytetracycline & 3 & 1 & 4 & \\
\hline Gentamicin & 4 & 0 & 4 & \\
\hline Tetracycline & 4 & 0 & 4 & \\
\hline Cefotaxime & 3 & 1 & 4 & \\
\hline Total & 14 & 6 & 20 \\
\hline
\end{tabular}

Table 3 of chi-square analysis shows that the level of susceptibility of E. coli to antibiotics is strongly relatedto the type of antibiotic with $\mathrm{p}<0.05(\mathrm{p}$-value $=0.012)$. The results showed that $E$. coli was resistant to Penicillin G, Oxytetracycline, and Cefotaxime with Penicillin $\mathrm{G}$ having the highest resistance value. These results are in line with Mustika et al. (2015) who stated that $100 \%$ of E. coli from the feces of Bali cattle at South Kuta district Badung Bali samples were resistant to penicillin $\mathrm{G}$.

Escherichia coli in this research was resistant to Penicillin $G$ because Penicillin $\mathrm{G}$ is a class of antibiotics beta-lactams. It is well-known that Gram-negative bacteria such as E. coli have beta-lactamase enzymes, which capable of inactivating beta-lactam antibiotics (Bradford, 2001). E. coli resistance to penicillin can be also caused by the frequent use of Penicillin in the treatment of cattle so that the bacteria have adapted. This statement is supported by Siswanto \& Sulabda, (2018) which stated that the residue of Penicillin $\mathrm{G}$ in Bali beef is $1.66 \%$ of the 60 samples collected from five markets throughout Bali. $E$. coli in this research is also resistant to Oxytetracycline because these antibiotics have been used since ancient times for various cases of a disease in livestock. Reig \& Toldra (2008) stated that the type of antibiotic that is most oftenly found in livestock products, especially meat is Tetracycline antibioticsincluding Oxytetracycline.

This fact make it possible that $E$. coli has been exposed to antibiotics such as Penicillin G and Oxytetracycline so this bacteria adapted, bychanging metabolic pathway that can fight antibiotics or by producing enzymes that can inhibit the action of antibiotics. Van Hoek et al. (2011) stated that bacterial resistance to antibiotics can occur by enzymatic 


\section{JURNAL BIDDJATI}

http://journal.uinsgd.ac.id/index.php/biodjati

modification or the bacteria has an alternative metabolic pathway for antimicrobials.

Escherichia coli in this research is also resistant to Cefotaxime. Cefotaxime is a third-generation cephalosporin antibiotic of antibiotics beta-lactams class. In this case, $E$. coli can produce the Extended-spectrum $\beta$-lactamase (ESBL) enzyme to inactivating beta-lactam antibiotics such as Cefotaxime. Extended-spectrum beta-lactamase is an enzyme produced by gram-negative bacteria of the Enterobacteriaceae family including $E$. coli and has increased activity in hydrolyzing $\beta$-lactam antibiotics, especially oxyiminocephalosporins (Bradford, 2001).

Escherichia coli samples that were isolated from the feces of Bali cattle with reproductive disorders in Lando Village, East Lombok Regency showed multidrug resistance with resistance to Penicillin G, Oxytetracycline, and Cefotaxime. Bacteria that are resistant to Cefotaxime can be used as an indication of the production of the Extendedspectrum $\beta$-lactamase (ESBL) enzyme. $E$. coli with multidrug resistance occurs due to the adaptation of bacteria to antibiotic stress by modifying the production of $\beta$-lactamase enzymes. Enzyme modification has been proven by the emergence of Extendedspectrum $\beta$-lactamase (ESBL) produced by $E$. coli which causes multidrug resistance which has been detected in $8.6 \%$ of 220 samples of cow feces at slaughterhouses in Bogor (Sudarwanto et al., 2016).

$$
\text { Escherichia coli with multidrug }
$$
resistance can occur because the gene encoding the Extended-spectrum $\beta$-lactamase (ESBL) produced by E. coli can be transferred vertically or horizontally. Vertical transfer can occur in bacterial offspring when they propagate, while horizontally there can be an exchange of plasmids carrying these genes in the bacterial community, either in the reproductive tract or the environment (Colodner \& Raz, 2005). The resistant E. coli is of course very easy to be excreted through feces into the environment around people's farms. Farmers who lack knowledge about sanitation management will trigger bacterial contamination in the environment which will endanger the health of farmers and the environment.

This study has succeeded in isolating $E$. coli from 4 fecal samples of female Bali cattle with reproductive disorders in Lando Village, East Lombok Regency. The results of this study have shown that $E$. coli from Bali cattle feces has experienced multidrug resistance to the antibiotics Penicillin G, Oxytetracycline, and Cefotaxime and indicates the presence of E. coli which produces Extended-spectrum $\beta$-lactamase (ESBL) enzymes that can harm human health and the environment.

Based on the results of this study, it can be concluded that E. coli isolated from 4 fecal samples of female Bali cattle with reproductive disorders had resistance to the antibiotics Penicillin G, Oxytetracycline, and Cefotaxime and indicated the presence of $E$. coli which produces the Extended-spectrum $\beta$-lactamase (ESBL) enzyme which can endanger human health and the environment. The research on E. coli encoding antibiotic resistance genes with one health approach is very necessary to anticipate the spread of these bacteria to humans and the environment.

\section{ACKNOWLEDGMENTS}

Many thanks to the Universitas Pendidikan Mandalika (UNDIKMA) which has funded this research. Thanks also to the Pade Angen Livestock Farmers Group and the Health Testing and Calibration Laboratory of West Nusa Tenggara Province for their cooperation in sampling and testing. 


\section{JURNAL BIDDJATI}

http://journal.uinsgd.ac.id/index.php/biodjati

\section{REFERENCES}

Aminuddi, S.P, Alpian, S.B, Dita, P. \& Kholik. (2020). Identification of Gram-Negative Bacteria of Bali Cattle with Repeat Breeding Cases on East Lombok, West Nusa Tenggara Province J. Phys.: Conf. Ser. 1430(1), 012013.

Badan Pusat Statisika (BPS). (2020). Provinsi Nusa Tenggara Barat dalam Angka. BPS Provinsi NTB, 241-242. Retrieved from https://ntb.bps.go.id/

Bradford, P. A. (2001). Extended-spectrum Beta-lactamases in the 21st Century: Characterization, Epidemiology, and Detection of this Important Resistance Threat. Clinical Microbiology Reviews, 14(4), 933-951.

Clinical and Laboratory Standards Institute (CLSI). (2012). Performance Standards for Antimicrobial Disk Susceptibility Tests; Approved Standard-Eleventh Edition. USA: Clinical and Laboratory Standards Institute.

Colodner, R. \& Raz, R. (2005). Extendedspectrum beta-lactamases: the end of cephalosporins?. The Israel Medical Association journal, IMAJ, 7(5), 336338.

Cornelissen, C. N., Fisher, B. D. \& Harvey R. A. (2013). Lippincott's Illustrated Reviews: Microbiology.3th. Philadelphia: Lippincott Williams \& Wilkins, a Wolters Kluwer business, p: 111-5.

Dibia, I, N., Dartini, N. L. \& Arsani, N, M. (2015). Gangguan Reproduksi Ternak Sapi di Pulau Lombok, Provinsi Nusa Tenggara Barat. Buletin Veteriner, BBVet Denpasar, XXVII(87).

European Food Safety Authority (EFSA). (2011). Scientific Opinion on the Public Health Risks of Bacterial
Strains Producing Extended-spectrumLactamases and/or AmpC-lactamases in Food and Food-producing Animals. EFSA J, 9, 1-95.

Food \& Agriculture Organization (FAO). (2016). Drivers, Dynamics and Epidemiology of Antimicrobial Resistance in Animal Production. Retrieved from http://www.fao.org/ publications/card/en/c/d5f6d40d-ef084fcc-866b-5e5a92a12dbf/

Gunawan., Nurmayani, S., Mandrasari, J., Tirtasari, K. \& Kholik. (2018). Antimicrobial Resistance of Escherichia coli that Isolated from Fecal samples of Bali Cattle at Local Farm on Lombok Island. Jurnal Sangkareang, 4(3), 1013.

Kamaruzzaman, E. A., Aziz, A., Bitrus, A. A., Zakaria, Z. \& Hassan L. (2020). Occurrence and Characteristics of Extended-Spectrum $\quad \beta$-LactamaseProducing Escherichia coli from Dairy Cattle, Milk, and Farm Environments in Peninsular Malaysia. Pathogens, 9(12), 1007. .

Kholik, Agustin, A. L. D., Atma, C. D., Munawaroh, M., Ningtyas, N. S. I., Legowo, A. P. \& Sukmanadi, M. (2019). Bacterial Pathogens from CaveDwelling Bats that are a Risk to Human, Animal and Environmental Health on Lombok Island, Indonesia. EurAsian Journal of BioSciences, 13(2), 15091513.

Melia, J., Amrozi, A. \& Tumbelaka, I. I. T. A. (2014). Dinamika Ovarium Sapi Endometritis yang Diterapi dengan Gentamicine, Flumequine dan Analog Prostaglandin F2 Alpha (Pgf2 $\alpha$ ) Secara Intra Uterus. Jurnal Kedokteran Hewan, 8(2), 111-115.

Mustika, O., Putra Pinatih, K. \& Suardana, 


\section{JURNAL BIDDJATI}

http://journal.uinsgd.ac.id/index.php/biodjati

I. (2015). Uji Kepekaan Escherichia coli O157:H7 Feses Sapi di Kecamatan Kuta Selatan Badung Bali Terhadap Antibiotik. Indonesia Medicus Veterinus, 4(4), 342-350.

O’Neill, J. (2016). Tackling drug-Resistant Infections Globally: Final Report and Recommendations. In: Ro A, ed. Resistance. London, United Kingdom

Reig, M. \& Toldrá, F. (2008). Veterinary Drug Residues in meat: Concerns and Rapid Methods for Detection. Meat science, 78(1-2), 60-67.

Saputra, F., Sulsia, N., Agustin, A. L. D. \& Kholik. (2018). Isolation and Identification of Gram-Negative Bacterial Pathogens of Bat Guano From Liang Bukal and Liang Petang Cave on Sumbawa Island. Proceeding, Hemerazoa, Proc. of the 20th FAVA CONGRESS \& The 15th KIVNAS PDHI, Bali Nov 1-3, pp: 531533.

Siswanto \& Sulabda, I. N. (2018). Residu Antibiotik Tetrasiklin dan Penisilin dalam Daging Sapi Bali yang Diperdagangkan di Beberapa Pasar di Bali. Jurnal Veteriner, 19 (4), 947-501. Sudarwanto, M. B., Lukman, D. W., Latif, H., Pisestyani, H., Sukmawinata, E., Akineden, Ö. \& Usleber, E. (2016). CTX-M Producing Escherichia coli Isolated from Cattle Feces in Bogor Slaughterhouse, Indonesia. Asian Pac. J. Trop. Biomed, 6, 605-608.

van Hoek, A. H., Mevius, D., Guerra, B., Mullany, P., Roberts, A. P. \& Aarts, H. J. (2011). Acquired Antibiotic Resistance FGenes: an Overview. Frontiers in microbiology, 2, 203.

Vandepitte, J., Engbaek, K., Rohner, P., Piot, P. \& Heuck, C. (2003). Basic Laboratory procedures in clinical bacteriology 2nd ed. World Health Organization. Retrieved from https://apps.who.int/ iris/handle/10665/42696

Yusuf, J. J. (2011). A Review on Retention of Placenta in Dairy Cattles. International Journal of Veterinary Science, 5 (4), 200-207. 